\title{
The development of Cultural Tourism Route in 3 Southern Borders of Thailand to Support Muslim Travelers
}

\author{
Daleesah Dayee $^{1}$, Amran Jehsoh ${ }^{2}$, Yuttana Promny ${ }^{3}$ \\ 1,2,3 Narathiwat Community College \\ ${ }^{1}$ daleechah@gmail.com
}

\begin{abstract}
The objectives of this study were to study 1 . The needs of cultural tourism in 3 southern borders of Thailand 2 . To create cultural tourism route in 3 southern borders of Thailand to support Muslim Indonesian Tourist 3. To evaluate Muslim Indonesian Tourist's satisfaction of cultural tourism route in 3 southern borders of Thailand. Using Semi-structure interview a group of 6 people to find the need of traveling. Selected the cultural tourist attractions with the potential of Muslim Indonesian tourist's need for establishing cultural tourism route in 3 southern borders of Thailand. Tourism activities on this route has been tested to analyze and evaluate the potential of the route. Measured tourists' satisfaction by indepth interview. The study result showed that most of Muslim Indonesian tourists wanted to visit 3 southern borders of Thailand for cultural reasons due to halal approachability, multi-cultural reasons, Culture and historical linked of their own and want to learn about Thai Muslim way of life. The formation of tourism route conducted by selecting cultural tourist attractions with the potential of Muslim Indonesian tourist's need these include: religious place, ancient remains, local market, local museum and religious institution (Pondak). The evaluation of satisfaction showed that all 10 tourists satisfied with the route and suggested that primary facilities should be developed. Cultural tourism route should be systematically publicized. The result of this study will be the key information for all nations to use in their marketing to attract Muslim Indonesian and Muslim travelers around the world.
\end{abstract}

Keywords

Cultural Tourism Route, Three Southern Borders of Thailand, Muslim Travelers

Article Received: 10 August 2020, Revised: 25 October 2020, Accepted: 18 November 2020

\section{Introduction}

Muslim tourism market is a high potential and fast-growing market. Also, there is enormous money to generate in the tourism industry. It is expected that by 2025 there will be 200 million Muslim tourists which mainly choose to travel within the Islamic Cooperation Organization (IOC) countries only. Thailand is considered as the second choice after Singapore. (GMTI, 2017). The important factor that will attract Muslim tourists for non-Islamic Cooperation Organization Countries (Non-OIC) is creating environment and friendly atmosphere for Muslims (Arabnews, 2016). Moreover, Wauttichai Bhutae (2017) Pointed that ASEAN Muslim tourists mainly travel to Thailand for the purpose of relaxation because Thailand has many tourist attractions with great tourism potential that meet the requirement of Muslims, such as Halal food and Prayer room according to the Islamic requirement.

It is predicted that in 2030 the Muslim population will increase and by 2050 the Muslim population will be 3 billion which is one third of the world populations. It is also predicted that world tourism market will generate up to $\$ 3$ billion in 2026 (Center of Tourism Research and Development).A report from Travel company the Global Muslim Travel index (GMTI,2015) mentioned that 50 percent of Muslim tourists travel as a family, travel for business, health and relaxation, knowledge acquisition and learn about different cultures.

As mentioned earlier Muslim tourism market is a fast-growing market with enormous money to generate in the tourism industry. high spending markets open up tourism business opportunity in both direct and indirect. Hence, it is considered as interesting market to keep an eye on, this is the matter of many countries to try to focus on in order to meet the need of this market. The report by The MastercardCrescent Rating Global Muslim Travel Index 2019 (GMTI) on the growth of Halal tourism, showed that Indonesia is on the top of the list in term of having the most Muslim travelers alongside its neighboring country Malaysia, which both countries are in the Islamic Cooperation Organization (IOC). Thailand is on the second after Singapore compared to ten countries outside the Islamic Cooperation Organization (IOC) (GMTI,2019). Having said that top ten tourist visited Thailand does not consist Indonesian (Ministry of Sport and Tourism). Therefore, it is crucial to study the needs of Indonesian Tourist in Thailand and to design tourism route that suites the need of Indonesian Tourists. This is because it can encourage more tourist from Indonesia to Thailand.

\section{Research Objectives}

1. To study the needs of cultural tourism in the three southern border provinces of the Indonesian tourists.

2. To generate the cultural tourism routes in the three southern border provinces to support the Indonesian tourists. 3. To study the satisfaction of the Indonesian tourists towards the cultural tourism routes in the three southern border provinces.

\section{Research Methods}

This research used the qualitative research method by analyzing documents, interview, in-depth interview, nonparticipant observation, and in-depth data collection. The purpose is to study tourism needs by interviewing a sample 
group of 6 persons. The interview form was a SemiStructured Interview. The selected cultural tourist attractions were from the potential sites concordant with the needs of Indonesia's tourists. Moreover, there was coordination through the responsible persons in the communities where the cultural tourist attractions were located. They were recruited to support the tourists for making the cultural tourism routes in the three southern border provinces. The tourism activities were tested along the cultural tourism routes in the three southern border provinces. The objective was to analyze and evaluate the routes potentials, measure the satisfaction of the tourists by In-depth Interview, and behaviors observed during the tourism services.

\section{Results}

The research result of cultural tourism needs in the three southern border provinces of Indonesian tourists revealed as follows:

The purposes of traveling to the three southern border provinces were to go on a field trip, seeking knowledge, having the local food, and buying souvenirs from Pattani. For the residence, the Indonesia tourists needed the convenient 3 star hotels, located in the city. For the expenses, they need to pay for not over 2500-3500 baht per person per day.

According to the travel motivations in the three southern border provinces, the areas were different from other places in Thailand. The cultures here are similar to the ones in Indonesia. There have been histories connecting to Indonesia for a long time. Besides, the Malayu language used in these areas is almost the same as the Indonesian language.

Furthermore, it is worth to pay for traveling to this country. For the styles of tourist attractions, there were various forms as follows:

1. Historical attractions, ancient remains, and ancient cities;

2. The tourist attractions which indicate the history of the Malaya government for the Langkasuka Kingdom in the past;

3. The tourists need to see traces of the spreading system on Islamic religion in the Langkasuka Kingdom period that is connected to the Malayu Aceh, Indonesia;

4. The tourists need to visit the educational institute in the type of traditional Pono, which has still maintained the duty of producing the Islamic philosopher (Ulama) until the present time;

5. Cultural tourist attractions which have the inheritance of local wisdom which has been maintained, and the local flea markets, and community livelihood;

6. The tourists need to have local food in the form of Malayu and Arab cultures;

7. The tourists need to visit the various traditions and cultures mixed with Thai and Malayu.

The result of generating the cultural tourism routes in the three southern border provinces to support the Indonesian tourists indicated as follows:

According to the selection of cultural tourist attractions which have the potentiality concordant with the needs of Indonesian tourists, the researchers generated the cultural tourism routes in the three southern border provinces to support the Indonesian tourists by selecting the tourist attractions as follows:

1. Paya Indira Cemetery or Sultan Ismail Syah Cemetery is located at Ban Pare, Barahom Sub-district, Mueang Pattani District. This is the cemetery of the first Pattani governor, a Muslim upholding Islamic religion. Paya Indira was King Sri Wang Sa's son of the Gotham Ligai City (an ancient city of Yarang today). When the new Pattani City was established at Kreuse Bana, Paya Indira was appointed as Pattani Governor during B.E. 2043-2073. He founded Pattani City as the Nakhon Pattani Darus Salam and developed this city to be forceful;

2. Pattani Provincial Central Mosque the tourist attractions of Pattani was designed by beautiful and outstanding architectures. Furthermore, it is a religious place considered one of the most important centers for the people who uphold Islam as their religion in the southern region. The external shape of the Mosque got the model from the Taj Mahal. Anyone who has arrived in Pattani has to see the arts and beauty of the building features. Also, this Mosque is admired by TripAdvisor as the most beautiful Mosque in Thailand

3. Krue Se Mosque or Sultan Muzaffar Shah Mosque It is an old mosque more than 700 years old in Pattani Province. It is assumed the Mosque was contemporarily established in the 22nd Century of the Buddhist Era for the Ayutthaya Kingdom. Moreover, this Mosque can be called "Pintu Kerban Mosque", called by its doors' shape. The door appearance is a sharp bend as European Gothic, mixed with the architecture of the Middle East Region;

4. Pondok Dalor is an educational institute in a Pondok type, established in B.E. 2476, considered an old Pondok institute in Thailand. The purpose of this institute is to perform the duty as an educational center for communities. However, the curriculum is specific and focusing on Islamic Religion only. Pono is regarded as a learning resource about the Islamic religion, which is ancient in South-east Asia. Not educational provision, but also providing religion, language, culture, and customs of Muslims. Are crucial roles for this institute. It can be said that Pondok possesses the position of an Islamic educational institute which has stimulated the livelihood of Islam from waking up until going to bed, due to encourage the students to live in the society called 'Muslim Society' (Maimanee Raksa Promrach, 2016;

5. Ta Lo Ha Lor Community, Raman District, Yala Province. It is a community that has dagger craftsmen inherited from the past to the present time. "Raman Dagger" has a long history. The origin of the Raman Dagger started around 200-300 years ago. Raman Governor desired to possess the dagger as a respectable weapon, so he invited the craftsmen from Indonesia to make daggers at Raman City. Now, there is "Khun Tee Pa Lee Ah Ra Bu" to be the person who inherits the blood of Raman Dagger Craftsmen. $\mathrm{He}$ is concerned as a local wisdom teacher who is skilled in the ancient dagger. He transfers his knowledge base on the dagger to the youths who are new generations to further inherit this knowledge.

6. Al-Quran learning Center: Manuscripts the ancient Qurans which are exhibited between $150-1,112$ years old. The features consist of the covers made of leathers whereas their inside part was made of paper and barks. The letters 
were written in a Yawee (Malayu) and ancient Arabic language, with black ink. Some pages were decorated with five colors writing with different styles. Some designs were decorated as Chinese arts mixed with Arabic arts, including the decorated gold leaf. The sizes were from small to huge ones. These Qurans have been repaired and treated carefully from foreign countries. There have been numerous visitors interested in, especially the group of Muslim countries from both the Middle East and Asia regions. Besides, there have been students who are interested in history usually contact the Museum to ask for the visit and learning history in this Museum;

7. Khun Laharn Local Museum; is located at Ban Ka Deng, Laharn Sub-district, Narathiwat Province. The person who established this Museum is Mr. Rassamin Nititham. He inherits the intention of his ancestors to maintain the arts, local wisdom, and cultural learning resources to the next generations. The things which are shown consist of collections, donated stuff, and things bought by the Museum. The Museum cooperates with the folklores. It has got the construction of two story buildings. The downstairs shows the stories of backgrounds of this locality since the pre-history until the Langkasuka period, or during the time of Pattani Darussalam, including the time of Khun La Han and various crucial persons in the community;

8. Talo Mano Mosque (300 years Mosque) is an old mosque and has a long history. The Mosque was constructed in B.E. 2167 (1624). All its features were built from the Iron Wood. Wooden bolt was used as nails or screws. Its shape is in a Thai local building style, applied with the Chinese and Malayu arts. The most outstanding part of this building is over the roof, which has the base to support the gable as another floor. The Azan Tower was built as a Chinese building on the roof. A single piece of wood was used to make walls, the windows were punctuated as a ventilator and carved in leaves and flowers patterns mixed with the Chinese style.

9. Community market, and the flea markets in Pattani City;

10. Local food restaurants in Pattani Province;

11. CS PATTANI HOTEL; is a four stars level hotel located in Pattani center. This hotel is clean, convenient, and safe.

The research result of the satisfaction for Indonesian tourists towards the cultural tourism routes in the three southern border provinces found that:

The tourists' satisfaction was from the In-depth interview and behavior observed during the tourism service provided. The result revealed that all of the ten tourists were satisfied with the tourism routes. They gave some recommendations that can be summarized as follows:

Some unique areas were artistic and impressive such as a mosque that had the building style perfectly ancient and mixed. Moreover, tourism access was convenient. Shops were ready to give services, the community was safe, and the tourist attractions were connected with the communities. However, some tourist attractions had primary facilities, some had better management systems in terms of tourism activities and facilities.

For the suggestion, the tourist attractions should be developed their primary facilities to support the tourists both at present and in the future comfortably. Furthermore, the constructions should be treated nicely, and the entire sceneries also should be improved consistently. However, there has not been any tourist service point clearly. Moreover, some cultural tourism routes have not been promoted. On the other hand, some paths should be organized more systematically, and some areas should be repaired and renovated.

\section{Discussions}

According to the study of the cultural tourism needs in the three southern border provinces of the Indonesian tourists, most of the tourists needed to visit the three southern border provinces because halal food was generally available. This opinion is concordant with the research of Wuttichai Puteh. (2560) about the tourism behaviors in Thailand of the ASEAN Muslims, which was found that most of them preferred to use leisure time in Thailand because there were several potential tourist attractions, including the readiness of religious places for perform a ritual prayer of Salat, and halal food service. Furthermore, the tourists realized the variety of cultures. Some cultures had a historical connection with their country. Therefore, they desired to travel to learn the way of the Muslim community. It conforms to the tourism company's report: the Global Muslim Travel Index (GMTI, 2015), which indicated that $50 \%$ of Muslim tourists preferred to travel to learn about other cultures. Furthermore, they traveled to visit their relatives and friends. Besides, the Malayu language made them easy to communicate with people there, including the worth of money

\section{Recommendations}

The recommendations got from the research entitled Development of Cultural Tourism Routes in Three Southern Borders of Thailand to Support Muslim Travelers are as follows:

For tourism enhancement in every country to reach the potentiality for supporting the Indonesian tourists: it should study the tourism behaviors of the Indonesian tourists in-depth. Besides, the sample group should come from all regions in Indonesia because each location has different cultures and livelihoods. The recieved information can be some further guidelines for tourism service.

\section{Conclusion}

The study on the development of Cultural Tourism Routes in three Southern Borders of Thailand to Support Muslim Travelers which focus on Indonesian Muslim tourists showed that, most of Indonesian Muslim tourists wanted to travel to three Southern Borders of Thailand and are interested in cultural tourism. This is because they can find halal food easily and its culture connects to their own country. Also they wanted to learn the way of life of Thai Muslim.

The result from the interview on the needs of traveling to the cultural tourism route in 3 Southern Borders of Thailand to support Indonesian tourists. The study showed that tourists 
wanted to travel to cultural attractions and wanted to see Malay culture that related to Langkasuka Kingdom which was an ancient Malay Kingdom. Moreover, they want to visit and learn about Pondok (Islamic Religious School) of the southern Thailand which has its renown on being Southeast Asia's oldest educational establishment

The results of measuring the satisfaction of tourists by interview with using motivational technique in order to get the truth answer. Tourists were also observed behavior during receiving the services. It showed that all 10 tourists were very satisfied with cultural tourism route in three Southern Borders of Thailand.

\section{References}

[1] Arab news. (2018). Malaysia Muslim travelers 'top choice. [Online]. Retrieved from http://www.arabnews.com/travel/news/713 816

[2] Center of Tourism Research and Development Chiang Mai University. (2017). Halal Tourism. [Online]. Retrieved from:

http://www.sri.cmu.ac.th/ ctrd/uploads/fil es/file_20190301_1551406433.pdf.

[3] Maimanee Ruksapromrach.(2016).The importance of Pondok in southern localMuslim community.[Online]. Retrieved from: https://lekprapai.org/home/view.php?id=798

[4] MasterCard\&CrescentRating. (2015). Master-card-Crescent Rating Global Muslim Travel Index 2015. [Online].Retrieved from https://newsroom.mastercard.com/mea/file s/2015/03/GMTI_report_FINAL1.pdf

[5] Ministry of Tourism and Sports. (2016).Situation and trends of Tourism affecting strategy of Ministry of Tourism and Sports.

[6] Wuttichai Puteh.(2017).ASEAN Muslim tourist behavior in Thailand. [Online]. Retrieved from http://libdoc.dpu.ac.th/mtext/thesis/zipf/W uttichai_P.pdf 